\title{
Pengaruh Pelatihan Terhadap Prestasi Kerja Karyawan Pada Unit HCBP PT Telekomunikasi Indonesia (Tbk)
}

\author{
Selfira Rizqi Nursyahputri ${ }^{1}$, H. Romat Saragih ${ }^{2}$ \\ Universitas Telkom \\ ${ }^{1}$ np.selfira@gmail.com \\ ${ }^{2}$ saragih@ypt.or.id
}

\begin{abstract}
ABSTRAK
Tujuan dari penelitian ini untuk mengetahui pengaruh dan menganalisis bagaimana pelatihan yang diberikan oleh perusahaan, bagaimana prestasikerja yang dihasilkan oleh para karyawan, dan besarnya pengaruh pelatihan terhadap prestasi kerja karyawan pada Unit HCBP (Human Capital Business Partner) PT Telekomunikasi Indonesia (Tbk).Metode penelitian yang digunakan adalah metode kuantitatif dengan jenis penelitian deskriptif kausalitas.Pengambilan sampel yang dilakukan menggunakan teknik sampling jenuh, dengan jumlah responden sebanyak 57 orang. Teknik analisis data yang digunakan adalah analisis deskriptif dan analisis regresi linier sederhana. Hasil penelitia menunjukan kedua variable dari seluruh dimensi memperoleh nilai rata-rata dalam kategori baik. Kesimpulan penelitian menunjukan bahwa pelatihan berpengaruh signifikan terhadap prestasi kerj akaryawan.
\end{abstract}

Kata Kunci : Pelatihan, Instruktur Pelatihan, Prestasi Kerja Karyawan, Sumber Daya Manusia

\begin{abstract}
The purpose of this study is to determine the effect and analyze how the training provided by the company, how the work performance produced by the employees, and the magnitude of the effect of training on employee performance at the HCBP Unit (Human Capital Business Partner) PT Telekomunikasi Indonesia (Tbk). The research method used is a quantitative method with a type of descriptive causality research. Sampling was done using a saturated sampling technique, with the number of respondents as many as 57 people. The data analysis technique used is descriptive analysis and simple linear regression analysis. The results of the study show that the two variables from all dimensions obtain an average value in the good category. The conclusion of the study shows that training has a significant effect on employee work performance.
\end{abstract}

Keywords:Training, Training Instructors, Employee Performance, Human Resource

Naskah diterima: 27 Juli 2019, direvisi: 26 Agustus 2019, diterbitkan: 16 September 2019

ISSN: 2355-0295, e-ISSN: 2549-8932 


\section{PENDAHULUAN}

Dalam menghadapi zaman globalisasi, banyak tantangan yang harus dihadapi oleh perusahaan dalam rangka memenangkan persaingan. Untuk dapat bertahan dan memenangkan persaingan, perusahaan dituntut memiliki keunggulan bersaing. Salah satu faktor yang dapat dijadikan pegangan perusahaan dalam menciptakan keunggulan bersaing adalah mempunyai sumber daya manusia yang berkualitas dan dapat memberikan kontribusi bagi perusahaan. Keberhasilan perusahaan sangat ditentukan oleh kualitas orang-orang yang bekerja di dalamnya. Setiap perusahaan berusaha meningkatkan serta mengembangkan program peningkatan prestasi kerja karyawan. Untuk mencapai tujuan yang telah di tetapkan, suatu perusahaan perlu menggerakan serta memantau pegawainya agar dapat mengembangkan seluruh kemampuan yang dimilikinya. Dalam penelitian Effendi (2018) semakin banyak karyawan yang berprestasi kerja tinggi, maka kinerja dan produktivitas perusahaan akan meningkat dan perusahaan dapat bertahan dalam persaingan bisnis serta dapat semakin berkembang dan maju. Penilaian prestasi kerja dilakukan oleh setiap perusahaan untuk melihat sampai sejauh mana perkembangan kualitas karyawan. Menurut Hasibuan (2008:94), Prestasi kerja adalah suatu hasil kerja yang dicapai seseorang dalam melaksanakan tugas-tugas yang dibebankan kepadanya yang didasarkan atas kecakapan dan kesungguhan serta waktu. Oleh karena itu, perusahaan harus memberikan program yang berdampak positif dalam meningkatkan prestasi kerja.Mangkunegara (2014:13) faktorfaktor lingkungan yang mempengaruhi prestasi kerja adalah, kondisi fisik, peralatan, waktu, material, pendidikan, supervisi, desain organisasi, pelatihan, dan keberuntungan.Salah satu faktor yang dapat mempengaruhi prestasi kerja adalah pelatihan (Hasibuan, 2011:94).Pelatihan tidak hanya diperlukan sebagai formalitas kegiatan perusaan saja, akan tetapi sekaligus untuk memberikan dasar-dasar pengetahuan. Para karyawan juga dapat belajar untuk mengerjakan pekerjaannya dengan benar dan tepat. Pelatihan juga dapat memperkecil atau meninggalkan kesalahan-kesalahan yang pernah dilakukan karyawan sehingga mengurangi penurunan prestasi kerja pada masa yang akan datang. Hal ini didukung oleh pendapat Sutrisno (2011:151) yang menyebutkan bahwa pendidikan dan pelatihan merupakan kunci dalam manajemen yang memainkan peran penting dan strategis dalam meningkatkan prestasi kerja.Berdasarkan survey awal melalui pendistribusian kuesioner terhadap 10 karyawan menggunakan skala diferensial agar responden lebih leluasa untuk menentukan jawaban dengan range yg lebih luas, maka diperoleh hasil rekapitulasi kuesioner survey awal dengan pertanyaan pertama tingkat kepentingan adanya program pelatihan terhadap karyawan sebesar $89 \%$. Responden juga menyatakan bahwa bahwa program pelatihan sangat berpengaruh terhadap prestasi kerja karyawan sebesar $90 \%$. Hal ini yang mendasari perusahaan untuk membutuhkan sejumlah tenaga kerja yang berkualitas melalui program pelatihan. Dari uraian di atas tentang pelatihan dikaitkan dengan prestasi kerja karyawan maka dilakukan penelitian yang berjudul "Pengaruh Pelatihan Terhadap Prestasi Kerja Karyawan pada Human Capital Business Partner PT Telekomunikasi Indonesia (Tbk).

\section{KAJIAN LITERATUR Pengertian Prestasi Kerja Karyawan}

Prestasi kerja merupakan hasil kerja seseorang pegawai selama periode tertentu dibandingkan dengan berbagai kemungkinan misalnya standard, target/ sasaran atau kriteria yang telah ditentukan terlebih dahulu dan disepakati bersama (Saragih, 2017). Pemahaman tentang pengertian prestasi kerja dapat didefinisikan oleh beberapa para ahli, Menurut Hasibuan dalam penelitian Aulia Pratiwi (2015) mengatakan bahwa prestasi kerja artinya pegawai mampu mencapai hasil kerja yang dapat dipertanggung 
jawabkan kualitas maupun kuantitas dan bekerja secara efektif dan efisien. Hal ini menunjukkan bahwa pegawai dapat memanfaatkan waktu dan mempergunakan alat-alat dengan baik.Pengertian prestasi kerja menurut Byars dan Rue dalam Edy Sutrisno (2016:150) adalah mengartikan prestasi sebagai tingkat kecakapan seseorang pada tugas-tugas yang mencakup pada pekerjaannya. Pengertian tersebut menunjukkan prestasi kerja adalah hasil upaya seseorang yang ditentukan oleh kemampuan karaktristik pribadinya serta persepsi terhadap perannya dalam pekerjaan itu. Dari definisi-definisi para ahli di atas, dapat disimpulkan bahwa prestasi kerja adalah suatu catatan hasil kerja yang dicapai oleh seseorang sebagai hasil kesuksesan dalam melaksanakan tugas-tugas yang dibebankan kepadanya yang didasarkan atas kecakapan, pengalaman, dan kesungguhan serta dalam kurun waktu tertentu. Dimensi prestasi kerja menurut Sutrisno (2014:152), sebagai berikut:

Hasil Kerja

Tingkat kuantitas maupun kualitas yang telah dihasilkan dan sejauh mana pengawasan dilakukan.m

Pengetahuan Pekerjaan.

Tingkat pengetahuan yang terkait dengan tugas pekerjaan yang akan berpengaruh langsung terhadap kuantitas dan kualitas dari hasil kerja.

Inisiatif

Tingkat inisiatif selama melaksanakan tugaspekerjaan khususnya dalam hal penanganan masalah-masalah yang timbul.

Kecekatan Mental

Tingkat kemampuan dan kecekatan dalam menerima instruksi kerja dan menyelesaikan dengan cara kerja serta situasi kerja yang ada

Sikap
Tingkat semangat kerja serta sikap positif dalam melaksanakan tugas pekerjaan.

Disiplin Waktu dan Absensi

Tingkat ketepatan waktu dan tingkat kehadiran

\section{PengertianPelatihan}

Menurut Widodo (2015:82), pelatihan merupakan serangkaian aktivitas individu dalam meningkatkan keahlian dan pengetahuan secara sistematis sehingga mampu miliki kinerja yang professional di bidangnya. Pelatihan adalah proses pembelajaran yang memungkinkan pegawai melaksanakan pekerjaan yang sekarang sesuai dengan standar. Menurut (Rivai, 2013:213) pelatihan memiliki orientasi dan membantu pegawai untuk mencapai keahlian dan kemampuan tertentu agar berhasil dalam melaksanakan pekerjaannya. Simamora (1995:287) dalam Kamil (2012:4) mengartikan pelatihan sebagai serangkaian aktivitas yang dirancang untuk meningkatkan keahliankeahlian, pengetahuan, pengalaman, ataupun perubahan sikap seorang individu. Dengan demikian pelatihan merupakan upaya untuk mengembangkan ataupun menggali kemampuan yang dimiliki oleh seseorang sehingga memiliki skill, cara berfikir dan perbaikan sikap sesuai dengan yang dibutuhkan oleh suatu perusahaan ataupun instansi tertentu hingga dapat memecahkan permasalahan yang mungkin akan dihadapi dimasa yang akan dating. Dimensi Pelatihan menurut Desller (2011:244) bahwa dimensi dalam pelatihan terdiri dari:

Instruktur

Seorang pengajar yang cakap memberikan bantuan yang sangat besar kepada suksesnya program pelatihan. Instruktur menjelaskan secara keseluruhan tujuan dari pekerjaan kepada peserta pelatihan kemudian menjelaskan tugas-tugas khusus 
untuk melihat relevansi dari masing-masing pekerjaan dan mengikuti prosedur kerja yang benar, serta memiliki sifat yang sabar. Dengan indikator sebagai berikut:

1) Kualifikasi/ kompetensi yang memadai

2) Memotivasi peserta

3) Kebutuhan umpan balik.

Peserta Pelatihan

Seorang peserta hendaknya dilatih untuk macam pekerjaan yang disukainya dan cocok untuk pekerjaan, baik itu peserta manajerial maupun operasional. Dengan indikator sebagai berikut:

1) Semangat mengikuti pelatihan

2) Keinginan untuk memahami Materi

Materi program pelatihan harus dapat memenuhi kebutuhan organisasi dan peserta pelatihan. Materi pelatihan harus sesuai dengan kebutuhan peserta atau motivasi mereka rendah. Dengan indikator sebagai berikut:

1) Ketepatan materi dengan tujuan

2) Menambah kemampuan

Metode

Metode yang dipilih hendaknya disesuaikan dengan jenis yang akan dilaksanakan dan dapat dikembangkan oleh suatu perusahaan. Baik itu metode on the job maupun off the job. Dengan indikator sebagai berikut:

1) Metode pelatihan sesuai dengan jenis pelatihan

2) kerKesesuaian metode dengan yang efektif dengan materi

Tujuan Pelatihan

Tujuan pelatihan harus dapat memenuhi kebutuhan yang diinginkan perusahaan serta dapat membentuk tingkah laku yang diharapkan sera kondisi-kondisi bagaimana hal tersebut dapat dicapai dan dapat meningkatkan keterampilan, dan pengetahuan baik itu tujuan promosi atau mutasi. Tujuan ini menjadi standar terhadap kinerja individu, jika tujuan tidak terpenuhi, perusahaan dikatakan gagal dalam melaksanakan program pelatihan. Indikator keberhasilan pelatihan adalah sebagai berikut:

1) Keterampilan peserta pelatihan meningkat.

2) Pemahaman peserta pelatihan semakin baik.

\section{Hubungan Antara Pelatihan dengan Prestasi Kerja Karyawan}

Byars \& Rue dalam Sutrisno (2016:150), mengartikan prestasi kerja sebagai tingkat kecakapan seseorang pada tugas-tugas yang mencakup pada pekejaannya. Pelatihan merupakan proses memperbaiki keterampilan kerja karyawan untuk membantu pencapaian tujuan. Pada awalnya, pelatihan hanya diperuntukkan kepada tenaga-tenaga operasional, agar memiliki keterampilan secara teknis. Tetapi, kini karyawan administrasi maupun tenaga manajerial diberikan pelatihan oleh perusahaan. Menurut Bangun (2012:202) para manajer perusahaan telah menyadari betapa pentingnya pelatihan untuk dapat meningkatkan kepuasan kerja.

Menurut Alwi (2012:218), berdasarkan pengalaman praktek, pelatihan yang efektif dapat meningkatkan kinerja, meningkatkan moral, dan potensi-potensi organisasi. Tall \& Hall dalam Sutrisno (2007:72) menghasilkan kesimpulan bahwa dengan mengombinasikan berbagai faktor seperti teknik pelatihan yang benar, persiapan dan perencanaan yang matang, serta komitmen terhadap esensi pelatihan ; perusahaan dapat mencapai manfaat kompetisi yang sangat besar di dalam pasar yang sangat ketat.

Subekti \& Jauhar (2012:73) menyatakan bahwa latihan untuk karyawan, jika diberikan dengan tepat dan diselenggarakan dengan baik akan mendorong mereka untuk bekerja lebih keras lagi. Karyawan yang lebih mengetahui dengan lebih baik tugas dan tanggung jawabnya, akan berusaha mencapai tingkat prestasi kerja yang lebih tinggi. Jadi, pelatihan dan prestasi 
mempunyai hubungan yang sangat erat karena untuk dapat mencapai prestasi yang tinggi sangat ditentukan oleh adanya kemampuan dan keterampilan serta pengetahuan karyawan yang tinggi dari hasil pelatihan.

\section{Kerangka Pemikiran}

Penelitian ini dilandasi dengan dua teori, yaitu pelatihan dan prestasi kerja. Diantara kedua variabel yang dibahas, yang menjadi variabel independen atau variabel bebas adalah pelatihan. Variabel terikat atau variabel dependen dalam penelitian ini adalah prestasi kerja. Menurut Bernandin dan Russel dalam Sutrisno (2014:152) terdapat enam dimensi di dalam prestasi kerja, yaitu:

1) Hasil kerja

2) Pengetahuan pekerjaan

3) Inisiatif

4) Kecekatan mental

5) Sikap

6) Disiplin waktu dan absensi.

Karena variabel prestasi kerja dipengaruhi variabel pelatihan, dimana pelatihan juga dapat digunakan sebagai sarana untuk lebih mengaktifkan kerja para anggota organisasi yang kurang aktif sebelumnya, serta mengurangi dampak-dampak negatif yang dikarenakan kurangnya pendidikan, pengalaman yang terbatas, atau kurangnya kepercayaan diri dari anggota atau kelompok anggota tertentu (Sedarmayanti, 2013:198), maka variabel independen dalam penelitian ini adalah pelatihan.

Variabel pelatihan menggunakan teori Dessler (2011:224), dimana terdapat lima dimensi dari pelatihan yaitu:

1) Instruktur

2) Peserta pelatihan

3) Metode

4) Materi

5) Tujuan pelatihan
Pemilihan teori dimensi menggunakan Sutrisno (2014:152) dan Dessler (2011:244) dikarenakan unsur-unsur yang terkandung sesuai dengan fenomena yang terjadi di unit HCBP PT Telekomunikasi Indonesia (Tbk).

Pelatihan adalah suatu proses memperbaiki keterampilan kerja karyawan untuk membantu pencapaian tujuan perusahaan. Saat ini manajmen bersama-sama dengan para karyawan untuk mengidentifikasi tujuan dan sasaran strategis dalam mencapai tujuan perusahaan. Para manajer perusahaan telah menyadari betapa pentingnya pelatihan untuk dapat meningkatkan kepuasan kerja (Wilson, 2012:202). Alwi (2012:218) menyatakan bahwa berdasarkan pengalaman praktek, pelatihan yang efektif dapat meningkatkan kinerja, meningkatkan moral, dan potensipotensi organisasi. Selanjutnya Subekhti \& Jauhar (2012:73) menyatakan bahwa latihan untuk karyawan, jika pelatihan diberikan dengan tepat dan diselenggarakan dengan baik akan mendorong mereka untuk bekerja lebih keras lagi.

Untuk memperjelas arah penelitian yang menunjukkan bahwa ada pengaruh pelatihan terhadap prestasi kerja, maka berdasarkan uraian yang telah dikemukakan sebelumnya, secara skematis model kerangka pemikiran dalam penelitian ini seperti pada Gambar 1:

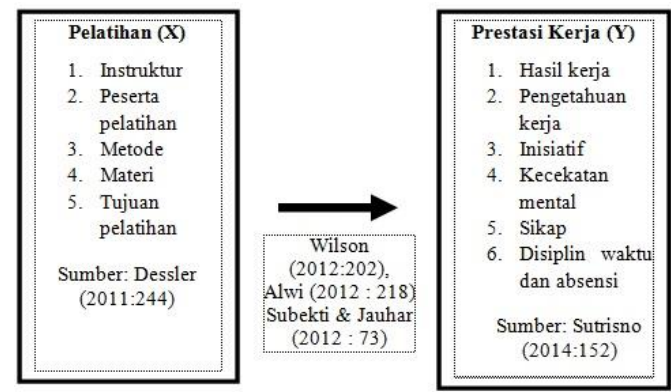

METODE PENELITIAN Jenis Penelitian

Metode penelitian yang digunakan dalam penelitian ini adalah metode kuantitatif. 
Menurut Sugiyono (2017:7) bahwa metode kuantitatif dapat diartikan sebagai metode penelitian yang berlandaskan pada filsafat positivism, digunakan untuk meneliti pada populasi atau sampel tertentu, teknik pengambilan sampel pada umumnya dilakukan secara random, pengumpulan data menggunakan instrument penelitian, analisis data bersifat kuantitatif/ statistic dengan tujuan untuk menguji hipotesis yang telah ditetapkan. Jenis penelitian ini adalah penelitian deskriptif. Selanjutnya penelitian ini menggunakan tipe penyelidikan kausal (konsklusif) atau biasa disebut sebagai penelitian ex post facto. Menurut Sujarweni (2014:8) penelitian ex post facto adalah penelitian yang dilakukan untuk mengungkap peristiwa yang sudah terjadi, dan kemudian meruntut ke belakang untuk mengetahui faktor-faktor yang dapat menimbulkan kejadian tersebut.

Skala instrument yang digunakan dalam penelitian ini adalah skala likert. Menurut Sugiyono (2013:168), skala likert digunakan untuk mengukur sikap, pendapatan, dan presepsi seseorang atau sekelompok orang tentang fenomena sosial. Dengan skala likert, maka variabel yang akan diukur dijabarkan menjadi indikator variabel. Kemudian indikator tersebut dijadikan sebagai titik tolak untuk menyusun item-item instrumen yang dapat berupa pertanyaan atau pernyataan.

\section{Populasi dan Sampel}

Dalam penelitian ini populasinya adalah karyawan unit HCBP Khusus Lokasi Kerja Bandung PT Telkomunikasi Indonesia, Tbk sebanyak 57 orang. Menurut Sujarweni (2014:65) sampel adalah bagian dari sejumlah karakteristik yang dimiliki oleh populasi yang digunakan untuk penelitian. Dalam penelitian ini judul populasi hanya 57 orang (kurang dari 100), maka seluruh populasi ini dijadikan sebagai sampel penelitian. (sampel jenuh).

\section{AnalisisDeskriptif}

Penelitian ini menggunakan teknik analisis deskriptif untuk mengetahui bagaimana tingkat prestasi kerja karyawan dan pelatihan yaitu dengan cara menghitung rata-rata dari setiap variabel penelitian. Teknik analisis linier sederhana untuk mengelola dan membahas data dalam menguji hipotesa yang diajukan. Sugiyono (2016:56), analisis regresi linier sederhana dapat digunakan untuk memprediksi seberapa jauh hubungan fungsional atau kausal satu variabel independent dengan satu variabel dependent.Adapun pendapat lain menurut Sugiyono (2015 : 207) Statistik deskriptif adalah statistik yang dipergunakan untuk menganalisa data dengan cara mendeskripsikan atau menggambarkan data yang sudah terkumpul sebagaimana adanya tanpa bermaksud membuat kesimpulan yang berlaku untuk umum atau generalisasi

\section{Uji Asumsi Klasik, Yang Terdiri Atas Uji Normalitas, Uji Heterokedastisitas}

Uji normalitas untuk melihat apakah nilai residual terdistribusi normal atau tidak (Sunjoyo, et al 2013:59). Menurut Priyatno (2012:158), heteroskedastisitas adalah keadaan dimana dalam model regresi terjadi ketidaksamaan varian dari residual pada satu pengamatan ke pengamatan yang lain. Model regresi yang baik adalah tidak terjadi heteroskedasitas.. Menurut Indrawati (2015: 191) model regresi yang baik adalah tidak terjadi heterokedastisitas. Model yang baik diperoleh jika tidak terdapat pola tertentu pada grafik, seperti mengumpul di tengah maka terjadi heterokedastisitas. Jika tidak ada pola yang jelas serta titik-titik menyebar diatas dan dibawah angka 0 pada sumbu Y maka tidak terjadi heterokedastisitas.

\section{Uji Hipotesis}

Menurut Ghozali (2013:98), uji statistik t pada dasarnya menunjukkan seberapa jauh 
pengaruh satu variabel penjelas atau independen secara individual dalam menerangkan variasi variabel dependent. Adapun menurut Indrawati (2015 : 94) mengatakan bahwa hipotesis adalah pernyataan sementara yang diperkirakan akan didukung oleh data empiris didalam penelitian.

Berdasarkan tujuan dari penelitian ini, maka variabel yang akan terdiri dari variabel eksogen (variabel penyebab) yaitu Pelatihan (X) dan variabel endogen (variabel akibat) yaitu Prestasi Kerja (Y). Salah satu cara melakukan uji $\mathrm{t}$ adalah dengan membandingkan nilai statistik $t$ dengan baik kritis menurut tabel.

Hipotesis yang diuji:

$H_{0}$ = format hipotesis awal (hipotesis nol).

$H_{a}=$ format hipotesis hubungan antar variabel.

Hipotesis yang akan diajukan dan dibuktikan kebenarannya adalah sebagai berikut:

1) $H_{0}: \beta_{1}=0$ atau $H_{a} \neq 0$,yaitu tidak terdapat pengaruh yang signifikan antara variabel Pelatihan (X) terhadap Prestasi Kerja Karyawan (Y).

2) $H_{a}: \beta_{1} \neq 0$ atau $H_{a}=0$,yaitu terdapat pengaruh secara signifikan antara antara variabel Pelatihan (X) terhadap Prestasi Kerja Karyawan (Y).

Untuk menentukan nilai t tabel ditentukan dengan tingkat kepercayaan $95 \%(\alpha=0,05)$ dengan derajat kebebasan $\mathrm{dk}=(\mathrm{n}-\mathrm{k}-\mathrm{l})$ dimana $\mathrm{n}$ adalah jumlah responden dan $\mathrm{k}$ adalah jumlah variabel. Dasar pegambilan keputusan pengujian adalah:

a. Jika $t_{\text {hitung }} \geq \mathrm{t}$ tabel maka $H_{0}$ ditolak dan $H_{a}$ diterima diterima, artinya Pelatihan berpengaruh signifikan terhadap Prestasi kerja karyawan

b. Jika $t_{\text {hitung }}<\mathrm{t}_{\text {tabel }}$ pada maka $H_{0}$ diterima dan $H_{a}$ ditolak, artinya Pelatihan tidak berpengaruh signifikan terhadap Prestasi kerja karyawan.

\section{PEMBAHASAN \\ Analisis Deskriptif}

Penelitian ini dilakukan untuk mengetahui bagaimana pengaruh Pelatihan terhadap Prestasi Kerja Karyawan pada Unit HCBP PT Telekomunikasi Indonesia (Tbk). Peneliti menyebarkan kuesioner ke 57 responden dan terdiri dari 31 item pertanyaan dan masing-masing pertanyaan diberikan lima alternative jawaban yang harus dipilih pada setiap pernyataan. Berikut merupakan hasil analisis deskriptif dari variabel prestasi kerja karyawan dan variabel pelatihan sebagaimana table 1

\section{Tabel 1 Hasil Analisis Deskriptif}

\begin{tabular}{cll}
\hline No & Variabel & $\begin{array}{l}\text { Nilai rata-rata } \\
\text { persentase } \\
\text { setiap variabel }\end{array}$ \\
\hline 1. & $\begin{array}{l}\text { Prestasi } \\
\text { Kerja }\end{array}$ \\
\hline 2. & Pelatihan & $75,73 \%$ \\
\hline \multicolumn{2}{l}{ Sumber: Data Hasil Pengolahan } \\
\multicolumn{3}{l}{ Peneliti }
\end{tabular}

Berdasarkan data di atas pada variable Prestasi Kerja mendapatkan presentase $80,06 \%$ dalam garis kontinum variable Prestasi Kerja berada dalam kategori baik. Variabel Pelatihan mendapatkan $75,73 \%$ dalam garis kontinum variable Pelatihan berada dalam kategor ibaik. Presentase tersebut menunjukkan bahwa karyawan unit HCBP PT Telekomunikasi Indonesia (Tbk) memiliki prestasi kerja karyawan dan pelatihan tinggi.

\section{Analisis Regresi Linier Sederhana}

Hasil output SPSS 23 terdapat pada Tabel 2

\begin{tabular}{|l|l|l|l|l|l|}
\hline \multicolumn{5}{|c|}{$\begin{array}{c}\text { Tabel 3 Hasil Persamaan Regresi } \\
\text { Coefficients }^{2}\end{array}$} \\
\hline \multirow{3}{*}{ Model } & Unstandardized Coefficients & $\begin{array}{l}\text { Standardized } \\
\text { Coefficients }\end{array}$ & & \\
\cline { 2 - 4 } & B & Std. Eror & Beta & T & Sig. \\
\hline (Constant) & 1.655 & .310 & & 5.333 & .000 \\
Variabel_X & .460 & .094 & .550 & 4.878 & .000 \\
\hline
\end{tabular}


Berdasarkan output Tabel 4 didapat koefisien regresi sehingga persamaannya adalah sebagai berikut:

$$
Y=1,655+0,460 X
$$

Persamaan regresi linear sederhana dapat diartikan sebagai berikut:

a. Nilai konstanta sebesar 1,655 menyatakan jika tidak ada Pelatihan (X) maka nilai konsisten Prestasi Kerja Karyawan (Y) adalah sebesar 1,655

b. Nilai koefisien regresi $\mathrm{X}$ bersifat positif sebesar 0,460 , artinya variabel $X$ memiliki hubungan searah dengan $\mathrm{Y}$ dan setiap pertambahan satu satuan Pelatihan (X) akan meningkatkan Prestasi Kerja Karyawan (Y) sbesar 0,460

\section{Pengujian Hipotesis (Uji T)}

Pengujian Hipotesis (Uji t) digunakan untuk menguji apakah pelatihan $(\mathrm{X})$ berpengaruh terhadap prestasi kerja karyawan (Y). salah satu cara melakukan uji t adalah dengan membandingkan nilai statistic $t$ dengan baik kritis menurut tabel.

Hipotesis yang akan diajukan dan dibuktikan kebenarannya adalah sebagai berikut:

a. $H_{0}: \beta_{1}=0$ atau $H_{a} \neq 0$,yaitu tidak terdapat pengaruh yang signifikan antara variabel Pelatihan (X) terhadap Prestasi Kerja Karyawan (Y).

b. $H_{a}: \beta_{1} \neq 0$ atau $H_{a}=0$,yaitu terdapat pengaruh secara signifikan antara antara variabel Pelatihan $(\mathrm{X})$ terhadap Prestasi Kerja Karyawan (Y).

Uji t menggunakan tingkat signifikan $(\alpha=$ 0,05 ) untuk diuji dua pihak maka kriteria pengujiannya sebagai berikut:

a. Jika $-\mathrm{t}$ tabel $<\mathrm{t}$ hitung $<\mathrm{t}$ tabel dan nilai Sig. $\alpha>0,05$ maka $\mathrm{H} 0$ diterima dan Ha ditolak, artinya tidak ada pengaruh signifikan pelatihan terhadap prestasi kerja karyawan b. Jika $\mathrm{t}$ hitung $\geq \mathrm{t}$ tabel atau $\mathrm{t}$ hitung $\leq-\mathrm{t}$ tabel dan nilai Sig. $\alpha<0,05$ maka H0 ditolak dan Ha diterima, artinya terdapat pengaruh signifikan pelatihan terhadap prestasi kerja karyawan.

Rumus yang digunakan dalam menguji hipotesis diatas yaitu menggunakan uji $\mathrm{t}$ student:

$$
\mathrm{t}-\text { hitung }=\frac{b}{S e(b)}=\frac{0,460}{0,094}=4,878
$$

Dengan $(\alpha=0,05)$ dan dk $=(n-k-1)$, dimana $\mathrm{n}$ adalah jumlah sampel dan $\mathrm{k}$ adalah jumlah keseluruhan variabel. Sehingga didapat nilai $57-2-1=54$. Dengan ketentuan tersebut diperoleh $\mathrm{t}$ tabel sebesar 2,00488. Berdasarkan perhitungan diatas, dapat diperoleh nili $\mathrm{t}$ hitung sebesar 4,878. Karena nilai t hitung $(4,878)>t$ tabel (2,00488), maka Ho ditolak. Artinya, terdapat pengaruh signifikan Pelatihan terhadap Prestasi keja karyawan pada unit HCBP PT Telekomunikasi Indonesia (Tbk).

\section{Koefisien Determinasi $\left(\mathbf{R}^{2}\right)$}

Perhitungankoefisiendetrminasudibantuden gan SPSS 23 padaTabel 3sebagaiberikut.

\begin{tabular}{l} 
Tabel 4 Uji Koefisien Determinasi \\
Model Summary ${ }^{6}$ \\
\begin{tabular}{|l|l|l|l|l|}
\hline Model & $R$ & R Square & $\begin{array}{l}\text { Adjusted } \\
\text { Square }\end{array}$ & $\begin{array}{l}\text { R } \\
\text { Std. Error of } \\
\text { the Estimate }\end{array}$ \\
\hline 1 & $.550^{\mathrm{a}}$ & .302 & .289 & .41818 \\
\hline
\end{tabular} \\
\hline b. Predictors: (Constant), Variabel_X \\
b. Dependent Variable: Variabel_Y \\
Sumber: Data Olahan Penulis
\end{tabular}

Berdasarkan output diatas diketahui nilai $\mathrm{R}$ square sebesar 0,302 dengan rumus sebagai berikut:

$$
\begin{aligned}
& \mathrm{KD}=\mathrm{r}^{2} \times 100 \% \\
& =(0,550)^{2} \times 100 \% \\
& =30,25 \%
\end{aligned}
$$

Dari hasil tersebut hubungan antara variabel bebas Pelatihan terhadap variabel terikat Prestasi Kerja Karyawan sebesar 30,25\%. 
Hal ini dapat diartikan bahwa pengaruh variabel Pelatihan (X) secara simultan terhadap variabel Prestasi Kerja Karyawan (Y) sebesar 30,25\%, sedangkan sisanya $69,75 \%$ dipengaruhi oleh variabel lain yang tidak diteliti dalam penelitian ini.

Hasil penelitian ini relevan dengan penelitian terdahulu (Rizal Armawansyah, 2016) menunjukkan bahwa pada variabel Pendidikan (X1) dan Pelatihan (X2) mampu memberikan kontribusi terhadap variabel Prestasi Kerja Karyawan (Y) sebesar $69,7 \%$, sedangkan sisanya sebesar $30,3 \%$ disebabkan oleh factor lain dan hasil penelitian dari (Agnes Tri Agata, 2017) bahwa pelatihan berpengaruh signifikan terhadap prestasi kerja karyawan. Pelatihan mampu menjelaskan prestasi kerja karyawan sebesar $42,9 \%$ dan sisanya $57,1 \%$ dipengaruhi oleh variabel lain.

\section{PENUTUP}

\section{Kesimpulan}

Berdasarkan hasil penelitian yang telah dilakukan oleh peneliti pada karyawan unit (HCBP) Human Capital Business Partner PT Telekomunikasi Indonesia (Tbk) tentang pengaruh pelatihan terhadap prestasi kerja karyawan, maka dapat diambil kesimpulan sebagai berikut:Prestasi kerja karyawan pada Unit HCBP PT Telekomunikasi Indonesia (Tbk) masuk dalam kategori baik. Kondisi tersebut menunjukkan bahwa Unit HCBP PT Telekomunikasi Indonesia (Tbk) memiliki karyawan berkompetensi yang sesuai untuk keberlangsungan perusahaan.Pelatihan yang diberikan pada Unit HCBP PT Telekomunikasi Indonesia (Tbk) masuk dalam kategori baik. Kondisi tersebut menunjukkan bahwa Unit HCBP PT Telekomunikasi Indonesia (Tbk) memiliki karyawan yang dapat menerapkan hasil pelatihan dengan baik.Pelatihan berpengaruh secara signifikan terhadap prestasi kerja karyawan pada Unit HCBP PT Telekomunikasi Indonesia (Tbk).
Terbukti dari hasil koefisien determinasi sebesar $30,25 \%$, sedangkan sisanya $69,75 \%$ dipengaruhi oleh variabel-variabel lain yang tidak diteliti dalam penelitian ini.

Berdasarkan kesimpulan dari hasil penelitian pengaruh pelatihan terhadap prestasi kerja karyawan pada unit HCBP PT Telekomunikasi Indonesia (Tbk), maka peneliti mengajukan beberapa saran untuk perusahaan dan penelitian selanjutnya yang dapat dijadikan solusi pertimbangan selanjutnya, antara lain sebagai berikut:

\section{REFERENSI}

Agata, Agnes Tri. (2017). Pengaruh Pelatihan Terhadap Prestasi Kerja karyawan Pada Unit Commercial Passenger Marketing PT. Kereta Api Indonesia (Bandung).Diambil dari: https://openlibrary.telkomuniversity. ac.id/

Alwi, Syafaruddin. (2012). Manajemen Sumber Daya Manusia Strategi Keunggulan Kompetitif. Yogyakarta: BPFE

Armawansyah, Rizal. Dkk. (2016).Pengaruh Pendidikan dan Pelatihan Terhadap Prestasi Kerja (Studi pada Karyawan PT. PLN (Persero) Distribusi Jawa Timur Area Malang). Diambil dari Universitas Brawijaya

Dessler, Gary. (2011). Manajemen Sumber Daya Manusia. Jakarta: Salemba Empat.

Effendi, Syafriana. (2018). Faktor-faktor yang Mempengaruhi Prestasi Kerja Studi Kasus pada Karyawan PT Danendra Agung Perkasa Jakarta. Jakarta

Ghozali, Imam. (2013) “Aplikasi Analisis Multivariate dengan Program IBM SPSS 20", Semarang: Universitas Diponegoro. 
Hasibuan, M. (2008). Manajemen Sumber Daya Manusia. Jakarta: PT. Bumi Aksara

Hasibuan, M. (2011). Manajemen Sumber Daya Manusia. PT. Bumi Aksara, Jakarta.

Indrawati. (2015). Metode Penelitian Manajemen Bisnis Konveregensi Teknologi Komunikasi dan Informasi. Bandung. PT RefikaAditama

Kamil. M. (2012). Model pendidikan dan Pelatihan (Konsep dan Aplikasi). Bandung: Alfabeta.

Mangkunegara, A. A. (2014). Manajemen Sumber Daya Manusia Perusahaan. Bandung: PT Remaja Rosdakarya.

Pratiwi, A. (2015). Pengaruh Kesesuaian Penempatan Pegawai Terhadap Prestasi Kerja Pegawai pada Build Better Communication - English Training Specialist. Jurnal Manjemen, Vol. 2 No. 21872. https://libraryeproceeding.telkomuni versity.ac.id/index.php/management/ article/view/759

Priyatno, Duwi. (2012). Cara Kilat Belajar Analisis Data dengan SPSS 20. Edisi Kesatu. Yogyakarta: ANDI.

Rivai, V. \& Sagala, E. J. (2013). Manajemen sdm untuk perusahaan. Jakarta: PT. Raja Grafindo Persada.

Saragih, Romat. (2017). External Environment Impact On Business Performance In Digital Creative Industry. International Journal of Advance and Applied Sciences. http://www.sciencegate.com/IJAAS/V4I9/Saragih.html

Sedarmayanti. (2013). Manajemen Sumber Daya Manusia, Reformasi Birokrasi Manajemen Pegawai Negeri Sipil. Rafika Aditama, Bandung

Subekhi, Akhmad \& Mohammad, Jauhar. (2012). Pengantar Manajemen Sumber Daya Manusia. Jakarta : Prestasi Pustaka Jakarta
Sugiyono. (2013). Statistika untuk Penelitian. Bandung : Alfabeta

Sugiyono. (2015). Metode Penelitian dan Pengembangan. Bandung: Alfabeta.

Sugiyono. (2016). Metode Penelitian Kuantitatif, Kualitatif dan $R \& D)$. (cet. ke-23). Bandung: ALFABETA.

Sugiyono. (2017). Metode Penelitian Kuantitatif, Kualitatif dan $R \& D$. Bandung: Afabeta.

Sujarweni, V. (2014). Metodologi Penelitian - Bisnis \& Ekonomi. Yogyakarta:

\section{PUSTAKABARUPRESS}

Sunjoyo. (2013). Aplikasi SPSS Untuk Smart Riset. Bandung: Alfabeta.

Sutrisno, Edy. (2011). Manajemen Sumber Daya Manusia. Jakarta: Kencana.

Sutrisno, Edy. (2014). Manajemen Sumber Daya Manusia. Cetak Ke Enam. Pranada Media Group, Jakarta.

Sutrisno, Edy. (2016). Manajemen Sumber Daya Manusia. (cet. ke-8). Jakarta: Kencana Prenada Media Group.

Widodo, S. E. (2015). Manajemen Pengembangan Sumber Daya Manusia. Yogyakarta: Pusaka Pelajar.

Wilson, Bangun. (2012). Manajemen Sumber Daya Manusia. Jakarta. Erlangga.

\section{BIODATA PENULIS}

Selfira Rizqi Nursyahputri. Lahir di Purworejo, 27 Juni 1997 dan menyelesaikan pendidikan S1 Administrasi Bisnis konsentrasi Sumber Daya Manusia di Universitas Telkom pada tahun 2019. 